\title{
Download
}

UDC 338.48:005.934(477) https://doi.org/10.17721/2308-135X.2021.63.25-30

Kryvolapov Eduard Anatoliyovych, Zaporizhzhia National University, Zaporizhzhia, Ukraine, e-mail: edward27772@gmail.com

Liuta Daryna Anatoliivna, Zaporizhzhia National University, Zaporizhzhia, Ukraine, e-mail: lyutadaryna@ukr.net

\section{THEORETICAL ASPECTS OF SAFETY IN TOURISM IN UKRAINE}

The purpose of this work is to reveal the theoretical aspects of tourism security in Ukraine, as well as to provide a generalized description of the components of the security system of the tourism sector of Ukraine.

Method. The study used general scientific methods, including analysis, scientific synthesis, analytical method, methods of comparison and generalization. The influence of the components of the security system of the tourism sector of Ukraine on the state and development of the tourism business in Ukraine is considered. The most important features of tourism safety in Ukraine are identified. An analysis of research on the impact of tourism on the world economy and conclusions on this issue. Ukraine is characterized in terms of tourist attractiveness in the world and the problem of this area at the international and regional levels is revealed. The scientists who have devoted their scientific works and research to the problem of formation, functioning and management of the tourist industry, namely: S.N. Dombrovska, NV Василиха, Z.I. Burak, A.V. Bakurova, M.Yu. Barna, S.W. Master and others, as well as the problem of safety and risks in the tourism sector: МВ Биржаков, Ю.Ф. Волков, М.П. Denisenko, NI Garanin, NP Казаков, B.M. Kozynets, NV Korzh, O.M. Kornienko, EL Pisarevsky, LL Rudenko and others. 
The scientific novelty lies in the fact that based on the existing approaches in the scientific literature to the definition of economic security, the components of the security system of the tourism business of Ukraine have been identified. Examples of the development of tourism and security in this area, both at the international and regional levels, are given. The main tasks of state regulation of security of the national tourist market of Ukraine are determined. Accordingly, the international approach to security issues in the field of tourism is described on the example of the General Military Council. Based on the Strategy for the development of tourism and resorts for the period up to 2026, an algorithm for building a system of economic security of a tourist enterprise has been developed.

Practical meaning. The results of this study are the basis for the study of the basics of ensuring safe and comfortable recreation of people in their spare time both in Ukraine and internationally. A list of measures to ensure the security of tourism in Ukraine as a whole is proposed.

Key words: tourism, economic security of tourists, economic security of tourist enterprise, security of tourist business in Ukraine, national security of tourist business, international security of tourist industry.

References

1. Korzh NV Formation of the system of economic security of the tourism industry as a component of sustainable tourism development in Ukraine. Economy. Management. Innovations. Electronic scientific professional publication. 2011. № 2. URL: http://www.nbuv.gov.ua/e-journals/eui/2011_2/11knvtvy.pdf

2. Bobkova AG Tourism safety: a textbook. Moscow: Federal Agency for Tourism, 2014. 272 p.

3. Zanosko OV Formation of systems of economic security of industry in Ukraine. Economy. 2011. № 2 (6). Pp. 17-19.

4. Master S.V. Peculiarities of state management of recreational tourism of Ukraine: monograph / ed. S.M. Dombrovska. Kharkiv, 2017. 198 p. 
5. Denisenko MP Algorithm for forming economic security systems of a tourist enterprise. Economics. Investments: practice and experience. Kyiv, 2013. № 24. S. 92-95.

6. Vildyakskin AS Combining tourism safety as a direction to increase the efficiency of the tourism business. Moscow: Russian Enterprise, 2008. Issue 1 (110), № 5. S. 135-137. 